\begin{tabular}{|r|l|l|}
\hline $\begin{array}{r}\text { Centro Interuniversitario } \\
\text { di Economia Applicata } \\
\text { alle Politiche per I'Industria } \\
\text { Io Sviluppo Locale } \\
\text { el'Internazionalizzazione }\end{array}$ & $\begin{array}{l}\text { - Università degli Studi di Ferrara } \\
\text { - Università degli Studi di Firenze } \\
\text { - Università Politecnica delle Marche }\end{array}$ & $\begin{array}{c}\text { C.MET } \\
\text { Working papers }\end{array}$ \\
ISSN: 2281-5023
\end{tabular}

\title{
Psychic distance and FDI: the case of China
}

\author{
Katiuscia Vaccarini
}

\begin{abstract}
The purpose of this paper is to investigate whether and to what extent psychic distance (PD) is considered by scholars as specific determinant of inbound and outbound foreign direct investments (FDI) in China. The finding of this study, which is a systematic literature review show that PD as a variable of FDI determinants seems to be under-investigated. The difficulty in quantifying the variable in international business might be one of the reasons. Nevertheless, the literature does raise awareness on distance issues and its multi-dimensions since it first appeared. Besides, the most applicable indexes elaborated by international business scholars are based on Hofstede's work, whose results are used both in psychology and management studies, pinpointing its interdisciplinary nature. This paper aims to systematize the limited and fragmented literature about non-tangible perceptions of distance between home and host economies this paper contributes in raising awareness . However, as part of a wider European Union project the ultimate results of the paper have not been leaked yet. This study provides useful insights and practical implications for international scholars regarding a more comprehensive review of PD, for managers in terms of raising awareness on PD and of the foreign environment (opportunities and difficulties which they are experiencing in the market context) as well as setting up and strengthening long-term cooperation between Europe and China and finally, policy makers on the issue of trade and investment flows between Europe and China, key barriers which affect companies and which require action at political and institutional level in order to ensure that opportunities are fully exploited
\end{abstract}

Keywords: psychic distance, China, FDI, determinants of FDI.

\author{
Katiuscia Vaccarini \\ University of Macerata, Italy \\ Katiuscia.vaccarini@unimc.it
}

\section{c.MET Working paper 3/2014 December 2014}

c.MET working papers are circulated for discussion and comment purposes. They have not been peer-reviewed or been subject to the review by the c.MET Board of Directors.

(C) 2014 by Katiuscia Vaccarini. All rights reserved. Short sections of text, not to exceed two paragraphs, may be quoted without explicit permission provided that full credit, including (C) notice, is given to the source. 


\section{INTRODUCTION}

There is considerable literature on developing countries and FDI in China (Wei \& Alon, 2010; Cheng \& Kwan, 2000; Zhang, 2000), however, the issue of PD as a determinant of FDI has been poorly addressed.

This study proposes a systematic review of the literature about whether and to what extent PD affects FDI, above all with respect to China-Europe and Europe-China bilateral relationships. Key aspects to be investigated are: is PD a key FDI determinant, especially in China and in the wider Asian context, affecting the decision making and internationalization processes? Therefore, is PD considered in models assessing FDI? Are there specific studies in the international business literature which deal with PD, FDI determinants and China?

\subsection{Perception and interpretation of the new environment}

First of all, a general introduction to PD in the field of international business is necessary. On the basis of the definition adopted by Johanson \& Vahlne $(1977,2009)$ and other scholars to describe the concept (Dow \& Karunaratna, 2006), PD can be considered as the perception of similarities and differences between home and host countries. The concept of PD is strictly related to cultural distance (e.g., Child et al. 2009).

When the local firm decides to go international, the new environment is more complex in its economic, cultural and political dimensions than the in the home country, not to mention the involvement of the uncertainty factor. The literature supports the importance of the cultural and the political dimensions along with the economic one (Markusen, 1995). According to Hosseini (2005), such a complex environment may not adequately fit in the theories explaining the behavior of multinational enterprises (MNEs) and FDI that have emerged since Hymer's study in 1960 (Hymer, 1976) ${ }^{1}$ and mainly considering the economic features. These theories would be incomplete if cultural and political dimensions are not considered. Hosseini (2005) goes even beyond FDI theory, recurring to the behavioural economics theories, which try to make economic theory consistent with the accumulated body of knowledge in all behavioural sciences. He suggests to utilize the behaviourally bases developed by Heiner (1985) in explaining FDI decisions since the reality of international environment faced by managers - economic, cultural and political - seems to reflect the behavioural economics

\footnotetext{
${ }^{1}$ Hymer's study is sbout the criticism of the neoclassical application of the portfolio flows theory. He transported the theory of foreign direct investment out of the neoclassical international theories of trade and finance and into industrial organization, the study of market imperfections.
} 
theories. Accordingly, MNEs are seen as a complex organization and its individual decision makers as boundedly rational real human beings who each posses different capacities to interpret information relevant to the FDI decision process (Hosseini, 2005). What he argues is strongly related with the PD perceptions as it is about subjective interpretation of the environment, similarities and differences.

\subsection{Relevance of the topic and gaps in the extant literature}

The internationalization process presupposes to develop an understanding of the cultural environment and this point does not seem to be always taken into account by FDI scholars (Hosseini, 2005). However, Lenartowicz and Roth (1999) suggest that "international business scholars generally recognize that culture is an important construct and that the field is in need of additional understanding about culture and its effects". With respect to this, Dunning (1980, etc.) argues that "firms which are best able to identify and reconcile (cultural) difference, or even exploit them to their gain, are likely to acquire a noticeable competitive advantage in the marketplace" (Lenartowicz \& Roth, 1999). The perceptions of distance could be practically translated into additional costs: the greater corporate headquarters and subsidiaries differ in their cultural characteristics, the more difficult it becomes to effectively supervise the various units. Drawing from earlier work by Kogut and Singh (1988), some scholars depict the headquarter-subsidiary relationship in terms of an agency (Roth \& O'Donnell, 1996), thus we can deduce that the agency cost increase as a function of cultural distance (Gomez-Mejia \& Polick, 1997).

To sum up, existing research on FDI determinants tends to focus on economic or standard factors, such as market size and trade openness (Chakrabarti, 2001; Hong, et al. 2001; Hong, 2007; Zheng, 2011). Ma, et al. (2008) use the concept of openness as the sum of exports and imports divided by GDP and not in terms of acceptance of foreign values, behavior, or rules. The majority of the reviewed articles contain a low number of references about the PD construct in the form of FDI determinant (Xiaojuan, et al. 2004; Ma, et al. 2008). Therefore, this work aims at filling the gap in the international business literature by investigating if noneconomic factors, specifically $\mathrm{PD}$, are considered by international scholars as FDI determinant and next to this, how many studies are related to the Chinese marketplace. Firstly, this is consistent with the literature since an approach based on the interaction between non-economic factors (e.g. differences in religion, language or cultural and PD) and economic factors could be a matter of concern to investors in their location decisions. Secondly, FDI is widely viewed as beneficial for host country's economic development since 
it is a vehicle for carrying finance and transferring advanced intangible assets - knowledge, technical and management skills ${ }^{2}$. PD is also relevant for the companies as it enables to carry out a correct and responsible management of the internationalization activities and benefit from in the long run.

For FDI-seeking policymakers an in-depth understanding of the underlying drivers of FDI helps the design of policies for the improvement of the country's future performance, especially the intangible FDI determinants. For example, most studies on FDI recognize the role of language as a component of cultural, psychic and administrative distance (Dow \& Karunaratna, 2006). Subsequently, factors affecting the location of FDI - both economic and non-economic - can provide guidance to policymakers in identifying not only the obstacles that some regions must overcome to attract FDI (Coughlin \& Segev 2000; Zhang, 2001b), but also opportunities and knowledge to exploit (Dunning, 2000).

FDI into a host country arise because of a number of theoretical and empirical reasons. Among other things, they may depend on the foreign direct investment in proximate countries (Li, et al. 2008). Such spatial interdependence may be complementary to non-spatial determinants, which in turn go hand in hand with non-economic or non-tangible factors. Those drivers have been largely ignored by the literature on FDI with only few studies dealing with such topics as PD or psychologically close investors and markets (Wei \& Alon, 2010; Chen \& Chen, 1998).

\subsection{China: current trends in the worldwide business scenario}

From an almost isolated economy in 1979, China has become the largest recipient of FDI in the developing world, and globally, the second after United States for many years (Coughlin \& Segev, 2000; Zhang, 2001a). Most important, China has recently begun to invert the trend of investment flows, gaining its place in the global scenario as far as outbound FDI is concerned (Spigarelli, 2009; 2010). Looking at the world main regional groupings, according to the United Nation conference on trade and development on 2013, China ranked first in the developing and transition economies and second in the world with inflows at an estimated US\$127 billion - including both financial and non-financial sectors (Unctad, 2013). In the Association of Southeast Asian Nations (ASEAN) FDI growth slowed, yet prospects for this region continue to be promising since more FDI arrives from China and Japan in a wide range of sectors, including infrastructure, finance and manufacturing. China is one of the countries

\footnotetext{
${ }^{2}$ However, according to some scholars FDI may crowd out local companies and have negative effects on economic development (Vintila, 2010).
} 
which largely drove inflows rise in 2013 following a surge in FDI and is particularly responsible for the rise in cross-border merger and acquisition sales in 2013, mainly driven by deals in East and South-East Asia. FDI flows could rise further in 2014 and 2015, to US\$1.8 trillion respectively, as global economic growth gains momentum (Unctad, 2013).

This paper is structured as follows. Section 2 provides a theoretical background including the FDI theory milestones and the most applied frameworks focusing on distance perceptions and some remarks on the most recent trends regarding institutional theory. In section 3 , the articles selection and classification methodologies are explained. Section 4 provides the analysis of the main findings. Section 5 discusses the evidence from the literature analysis and section 6 concludes the work with future lines, implications and limitations of research.

\section{THEORETICAL BACKGROUND}

Several contributions in the literature focus on FDI determinants. They could be divided into two major streams of perspectives: the micro perspective including contributions, such as organization, transaction cost theory, internationalization theory and the eclectic paradigm, and the macro perspective with contributions like orthodox trade theory, Kemp-MacDougall theory and product cycle theory, Heckscher-Ohlin-Samuelson paradigm (Samuelson, 1948). From a microeconomic viewpoint, FDI tries to explain the motivations for investment across boundaries from the point of view of the investor. Moreover, "it examines the consequences to investors, to the country of origin and to the host country, of the operations of the multinationals rather than investment flows and stock" (Vintila, 2010). From a macroeconomic point of view, FDI are considered a particular form capital flows across borders, which are found in the balance of payments and have such variables as capital flows and stocks, revenues obtained from investments. Regarding the macro perspective, on the one hand, FDI effects are often seen as generators of employment, high productivity, competitiveness, and technology spillovers. Especially for the least developed countries, FDI is synonym of exports, access to international markets and international currencies. On the other hand, FDI may have a negative impact on economic development. The positive or negative effects potentially depend on the nature of the sector in which the investment takes place (Vintila, 2010).

The main contributions in FDI theory can be highlighted as follows (Hosseini, 2005; Vintila, 2010; Bartels et al. 2014): production cycle theory, theory of exchange rate on imperfect capital markets, the internationalization theory, the eclectic paradigm (see Table 1.). 
Table 1. Milestones in FDI theory.

\begin{tabular}{|c|c|c|c|}
\hline Author & Year & Theoretical model & Model application \\
\hline Vernon & 1966 & $\begin{array}{l}\text { Production Cycle } \\
\text { Theory }\end{array}$ & $\begin{array}{l}\text { The four stages of production cycle - innovation, } \\
\text { growth, maturity and decline - explained certain } \\
\text { types of FDI made by US companies in Western } \\
\text { Europe between 1950-1970 in the manufacturing } \\
\text { industry. }\end{array}$ \\
\hline Cushman & 1985 & $\begin{array}{l}\text { Theory of Exchange } \\
\text { Rates } \\
\text { on Imperfect Capital } \\
\text { Markets }\end{array}$ & $\begin{array}{l}\text { Analysis of the foreign exchange risk from the } \\
\text { perspective of international trade. The author } \\
\text { analysed the influence of uncertainty as a factor } \\
\text { of FDI. } \\
\text { Real exchange rate increase stimulated FDI made } \\
\text { by USD, while a foreign currency appreciation } \\
\text { has reduced American FDI. }\end{array}$ \\
\hline $\begin{array}{l}\text { Buckley \& } \\
\text { Casson }^{3}\end{array}$ & 1976 & $\begin{array}{l}\text { The } \\
\text { internationalization } \\
\text { theory }\end{array}$ & $\begin{array}{l}\text { Demonstration that transnational companies } \\
\text { grow and are motivated to achieve FDI by } \\
\text { organizing their internal activities so as to } \\
\text { develop specific advantages, which then to be } \\
\text { exploited. }\end{array}$ \\
\hline Dunning & 1980 & $\begin{array}{l}\text { The eclectic } \\
\text { paradigm (OLI) }\end{array}$ & $\begin{array}{l}\text { OLI eclectic paradigm (ownership, location and } \\
\text { internationalization advantages) shows that OLI } \\
\text { parameters are different from company to } \\
\text { company and depend on context and reflect the } \\
\text { economic, political, social characteristics of the } \\
\text { host country. }\end{array}$ \\
\hline
\end{tabular}

(Source: own elaboration)

As showed in table 1., since every new evidence developed over the years has added some new elements and criticisms to the previous contributions, we cannot identify a generally accepted theory. However, Dunning's (1980) remains the dominant operational framework within international business to understand FDI motivations (Bartels et al. 2014). The original model was further developed over the years ${ }^{4}$.

\subsection{PD, internationalization and FDI}

According to some scholars, specific FDI determinants account for the following: exchange rates, market size, government policies and incentives, political risk, cost of labour, labour skills, trade openness and export orientation policy, and infrastructure (Zhang, 2001a, 2001b; Fung, et al. 2005; Chantasasawat, et al. 2010). However, two of the most applicable theories

\footnotetext{
${ }^{3}$ The internationalization theory was initially launched by Coase (1937) in a national context and by Hymer (1976) in an international context. After its elaboration by Buckley and Casson (1976), the theory was further developed by Hennart (1982) and Casson (1983)

${ }^{4}$ Its evolution from 1958 to 2000 is illustrated in detail by Ferreira et al. (2011).
} 
that are considered in this work provide details in the internationalization process, such as the Uppsala model (Johanson \& Vahlne, 1977; 2009) and Dunning's eclectic paradigm (Dunning, 1980 , etc.). In particular, the latter includes details regarding inbound and outbound FDI determinants.

The two theoretical frameworks have a common feature which is relevant to this study: the presence of the PD construct. PD appears firstly in the 1950s when Beckerman (1956) - and later Linnemann (1966) - starts to examine the concept, paving the way and raising interest in the fields of international business and international management. Beckerman demonstrates that PD influences trade patterns. He refers to economic distance in terms of transport costs and suggests that PD is meaningful in the form of gaining knowledge of foreign markets through personal contacts. Some scholars define PD as geography or transport costs (Linnemann, 1966; Leamer, 1974), while others (Gruber \& Vernon, 1979) argue that the concept should not be identified with transport costs alone. Instead, it should incorporate knowledge about sources and markets.

The appreciation of PD as a determinant of FDI, for example in Dunning's eclectic paradigm (Dunning, 1980) is preceded by a dominance of internationalization theory attributing to PD a fundamental role in the four-stage process developed by the Uppsala school (Johanson \& Vahlne, 1977). In order to adjust to the changes in the firm and its environment, internationalization consists of a series of incremental steps. PD is the main variable in this model and here is defined as the sum of factors preventing the flow of information from and to the market (Johanson \& Vahlne, 1977). This definition entails such differences between home and host country as language, education, business practices, culture, and development. The original Uppsala model of internationalization elaborated in the 1970s is later revised by the same authors, Johanson and Vahlne (2009) due to the changes in the international business scenario and dynamics. In their updated model they emphasize the importance of the network that a firm is able to set up in its national and international environment. In this new version they attribute a crucial role to the company networks, consistently with the fundamentals of international entrepreneurship, based on the recognition of business opportunities by international entrepreneurs and the network approach (McDougall \& Oviatt, 2005).

In relation with the definition of PD by Johanson and Vahlne in 1977, which includes the psychic and the cultural aspect, Hofstede in 1980 and later Kogut and Singh in 1988 in elaborate a classification of cultural distances in terms of cross-country distance that is used as a measurement scale to capture national differences (Hennart \& Larimo, 1998). The 
construct is generally analyzed at three main levels: country, firm and individual level (Hofstede, 1980; Forsgren, 2002; Cheng, 2006; Jiang, 2006; Brewer, 2011; Ambos \& Håkanson, 2013). The country level focuses on the values and behaviour of the society as a whole, the firm level is based on the company team and business practices and the individual level concerns the individuals' perceptions of distance. Nevertheless, Hofstede and Kogut and Singh's composite indexes do not capture the complexity of differences between the parent and the foreign country. Specifically, they neglect the role of societal institutions in disseminating and arbitrating cultural and social cues (Xu \& Shenkar, 2002). According to Shenkar (2001), the indexes do not apply to FDI as they fail to yield consistent empirical evidence and they include some hidden assumptions, named "illusions", such as the illusions of homogeneity and symmetry. The illusion of homogeneity takes for granted the fact that there is no difference of values in the same country, that is intra-country level, and according to the illusion of symmetry, the distance perceived from country A toward country B can be different than the one perceived from country B toward A.

The distance issue is strongly related to two critical steps in the FDI process: host country selection and foreign entry strategy (Xu \& Shenkar, 2002). The concept of distance in internationalization is examined not only under several perspectives and perceptions but also taking into account a variety of dimensions and features, for instance, geographical (Fung, et al. 2005; Zihui et al. 2008) and institutional distance, such as the degree of corruption (Chantasasawat, et al. 2010). Next to this, a cultural viewpoint (Cheng, 2006) in terms of ties (Chen \& Chen, 2008) or cultural and ethnical proximity (Parmentola, 2011) are also taken into account.

\subsection{PD and culture perceptions in the OLI paradigm}

Cultural and psychic distance, in particular, are mentioned in the OLI eclectic paradigm (Dunning, 1980, etc.) as key drivers in the FDI decisions since they pertain to location and internationalization choices. Accordingly, FDI is determined by three types of advantages: ownership, location, and internationalization (thus, OLI). The ownership advantage arises from the firm's size and access to markets and resources, the ability to coordinate complementary activities (e.g. manufacturing and distribution) and to exploit differences between countries. The distance issue may arise from differences in the form of culture (Hong \& Chen, 2001; Brouthers, et al. 1996; Jiang, 2006), bureaucratic procedures (Spigarelli, 2010) or country characteristics (Zihui, 2008). Those differences do not always guarantee the 
success of the choice, however in our case regarding China, their absence and the ignorance of the Chinese culture (e.g. the importance of guanxi) may lead to failure (Jiang, 2006).

The firm specific advantage is usually intangible and can be transferred within the MNE at low cost. Compared to a local competitor, a MNEs operating a plant in a foreign country faces additional costs that could include legal, institutional, cultural and language diversities. Location advantages of different countries are crucial to determine which will become a company's host country. Such advantages include differences in country's natural endowments, transport costs, macroeconomic stability, cultural factors, and government regulation. According to this model, PD belongs to the country specific advantage group since it is part of the social and cultural features, together with language, cultural diversities, general attitudes toward foreigners and the overall position toward free enterprise (Brouthers, et al. 1996). This sub-groups go along with economic and political advantages (Hong \& Chen, 2001; a, 201b, 2001; Jiang, 2006).

While quantities and qualities of the production factors, transport and telecommunication costs, scope and size of the market belong to the economic advantages and common and specific government policies that influence inward FDI flows, intra-firm trade and international production are part of the political advantages (Fung, et al. 2005). Evidences show that in determining FDI locations, transaction and coordination cost variables, such as interpersonal relations, information asymmetries, language and culture are more important than production-related variables (Dunning, 1997). Despite the fact that differences are not always translated into a success factor (Jiang, 2006), it is argued that the internationalization incentives arise from exploiting imperfections in external markets. They entail reduction of uncertainty and transaction costs to generate knowledge more efficiently than state-generated imperfections, for instance, tariffs, foreign exchange controls and subsidies. An integrated view of these advantages and the interaction with one another produce the final decision on FDI location (Jajri, 2009).

\subsection{OLI's evolution to OLMA and institutional theory traits}

Dunning's OLI theory (Dunning, 1980, etc.) provides with a framework for many researchers who examine the interaction between various determinants of international business activities and entry modes (Brouthers, et al. 1996, 1999; Tse, et al. 1997). Brouthers, et al. (1999) further suggest that this paradigm might be used as a normative model. It provides with a balanced overarching framework that helps to identify the determinants of the cross-border expansion strategy, especially in FDI (Dunning, et al. 2007). Dunning (2000) reconfigures the 
OLI paradigm to envelope asset FDI and MNEs activity. The OLI framework has been explained in details in most FDI literature (Ramasamy, 2003) since it is able to provide a theory for FDI activities under normal conditions. Nevertheless, Dunning himself admits that the paradigm is a general framework to determine the extent and the patterns of both foreign owned production and domestic production rather than a theory of MNE or of FDI (Dunning, 1993). This goes along with Hosseini's study (2005), since he proposes an alternative perspective to "read" the FDI decisions by applying a behaviourally based model (Heiner, 1985) because it seems to reflect the international reality, made up of not only economic factors, but also, political and cultural ones. A behavioural economics approach would enable to view a multinational firm as a complex organization in which all the three aspects intertwine and play a significant role.

Guisinger (2001) elaborates an evolved eclectic paradigm by replacing the "I" factor, which stands for "internationalization", with "M" for the "entry mode", shedding light on the distinction between factors affecting different modes of entry in the various countries. The model foresees the adaptation of the firm's operations to the international business environment building on institutional theory, hence OLMA stands for ownership, location, entry mode, and adaptation. Accordingly, there is a difference between foreign and domestic components of the environment. Within this context, North (2005) divides the environment into organizations and institutions. He names the institutions "geovalent component", in particular, referring to institutional rules, regulations, cultures and exchange rates as well as other elements that are geographically bound and in certain cases, but not always, follow national boundaries. It is about environmental forces that affect the firm but are not themselves organizations. This component is meaningful for adaptation and accommodation approaches to the international business environment (Guisinger, 2001), consistently with the role that PD plays in the international scenario. Next to the geovalent component, the author divides the environment in organizations, named "interactors".

As far as institutions is concerned, the literature seems to embed them into distance dimensions, essential in international business and international management research areas (Rottig \& Reus, 2009). Institutional distance measures have been much under the attention of and criticized by international scholars (Kogut \& Singh, Shenkar, 2001) for neglecting such assumptions as intra-country differences and intra-country heterogeneity of cultures. Evidence is large and not limited to MNEs (Kostova, 1999; Xu \& Shenkar, 2002) and recent streams of research increasingly consider their vital impact on firms, their performance, their patterns of expansion and strategies. 
When operating in distant environments that differ from the source context, institutional distance is considered as one of the key drivers of the liability of foreignness that firms need to face (Gehmawat, 2001; Zaheer, 1995). The literature identifies three main institutional pillars, regulative, normative and cognitive (Kostova, 1999) that are strictly related to perceptions and subjective evaluation of the foreign environment. Apart from the regulative pillar regarding the existing laws and rules in a particular context, the normative and the cognitive dimensions are particularly relevant to the present research. The former is about individuals' values and norms and it is related to the social life, while the latter concerns categories at cognitive level shared by people in a particular country (Kostova, 1999), that is how people categorize their perceived reality. In the conceptual-theoretical work on institutional distance the normative and cognitive distance are not always considered explicitly, but embedded in the cultural dimension (Kogut \& Singh, 1988).

\subsection{OLI's integration with LLL theory and emerging countries MNEs internationalization}

Moving on the developments of the OLI paradigm, Mathews (2006) proposes the so-called linkage, leverage and learning (LLL) framework, which has been defined as a complement of Dunning's eclectic paradigm. This contribution acknowledges that emerging countries MNEs may be willing to invest in more advanced countries to access or augment their resources, rather than to exploit their ownership advantage. Linkages with foreign firms would foster the access to the resources they lack internally, subsequently, leverage would refers to how they can access the potential resources. The interaction between linkages and leverage may conduce to learning, that is the final outcome based on the opportunity to better understand how to operate internally and to allow firms to be competitive in the global markets.

In the context of emerging economies, MNEs seem not to follow the traditional patterns of development, therefore the OLI paradigm is not properly applicable. It does not appear to explain the outreach toward international markets (Dunning, 1993; Hosseini, 2005). MNEs from emerging economies internationalize not because of their current advantages on a global scale, but to achieve competitive advantages (Spigarelli, 2010). The exploitation of opportunities thanks to their positions as late entrants to the market seems to be a key factor

of global success. This goes along with the fundamentals of international entrepreneurship proposed by McDougall and Oviatt (2005). Thus, Spigarelli (2010) proposes that a new ad hoc theory is needed to interpret the flows of international investment following the recent 
phases of expansion, especially regarding the Chinese case. Other scholars argue that countries experiencing a rapid development (e.g. China), are arising new models of internationalization, therefore the need to revise and consolidate the theoretical frameworks that the current literature offers (Aulakh, 2007).

\section{METHODOLOGY}

The criteria used to collect the articles is based on the strings "foreign direct investment*", "determinant*", "China" in the abstract of the following databases: Business Source Premier, EconLit, Regional Business News accessed through EBSCOhost and ABI/INFORM. This searching procedure delivered 35 results and the above mentioned keywords were searched in the abstract.

As about the criteria of inclusion and exclusion, only documents focused on China and FDI were considered relevant. Four articles were "partly relevant" to the research since they deal with China, but focus on other issues: the "China effect" (Chantasasawat, et al. 2005; 2010), the determinants of disparities in inward FDI in China (Zheng, 2011) and the Japanese investment in Asian host countries in general (Langhammer, 1991).

Other six articles were "not relevant" since they explore the regional per capita income distribution in China (Villaverde \& Maza, 2012), the determinants of city growth in China (Anderson \& Ge, 2004), the firm specific effects on location decision of FDI in China (Hong, 2007), the influence of FDI on the growth of Malaysia (Jairi, 2009), the global city-regions in China, (Zhao \& Zhang, 2007), patterns and determinants of FDI in Malaysia from a comparative Southeast Asian perspective (Athukorala \& Waglé, 2011), the diffusion and absorption of technological knowledge (Liao, et al. 2012), and finally, one of these articles is about FDI and Russia (Iwasaki \& Suganuma, 2005). These studies resulted from the searching procedure because they include the above mentioned keywords searched in the abstract, but are not purposeful for our research questions: is PD a key FDI determinant in China and to what extent? ? $^{5}$ Although they were not relevant to the Chinese case, they were useful to analyse whether PD is a relevant object of studies among FDI determinants, regardless the involvement of the Chinese marketplace.

Next to the documents obtained from the above mentioned databases, the snowballing technique was adopted on the basis of the relevant citations in the 35 results. This additionally

\footnotetext{
${ }^{5}$ Another pertinent question would be how scholars identify and isolate the variable in their models of analysis, but there are not consistent results about this as the most rigorous models are related to other variables, which are quantitatively measured (Zihui, et al. 2008; Sanfilippo, 2010; Villaverde \& Maza, 2012).
} 
searching procedure produced 82 documents for a total amount of 117 sources. The following sections analyse and discuss the key findings.

\section{ANALYSIS}

Evidences show that studies regarding PD, FDI determinants and the Chinese marketplace are very few. Specifically, the works on PD that have been collected are 17 and only 6 out of them focus on FDI (see Table 2. below).

Table 2. Studies about PD, China, and FDI determinants. (Source: own elaboration)

\begin{tabular}{lll}
\hline Authors & Year of publication & Academic journal \\
\hline Chen, H., Chen, T.-J. & 1998 & $\begin{array}{l}\text { Journal of International Business } \\
\text { Studies }\end{array}$ \\
\hline Forsgren, M. & 2002 & \begin{tabular}{l} 
International Business Review \\
\hline Zihui, M., Ruilong Y., Zhang, Y
\end{tabular} \\
\hline Buckley, P.J., Cross, A.R., Horn, S.A. & 2008 & Economic Papers \\
\hline Hashim, F. & 2012 & Business History \\
\hline $\begin{array}{l}\text { Amighini, A.A., Rabellotti, R. } \\
\text { Sanfilippo, M. }\end{array}$ & 2013 & Review of Business \& Finance Studies \\
\hline
\end{tabular}

Firstly, Chen \& Chen (1998) refer to psychological closeness and proximity instead of PD. Concerning investors, China is psychologically close to Taiwan in terms of culture and communication, although they are distant in terms of political and economic systems. The authors refer to the perception of location familiarity that measures investors' prior market experience in the host country in the form of exporting or licensing, and to the investors' perceived distance of the host country, in the form of affinities and similarities of culture, political system, economic conditions and communication. They confirm Grosse and Trevino's (1996) findings on the relevance of cultural and geographical distances, which discourage FDI decisions. Secondly, Forsgren (2002) does consider PD in his critical review of the Uppsala model of internationalization, adding a controversial point. He argues that PD is basically a concept regarding the national level, while foreign investment is a phenomenon involving the management level. Ambos \& Håkanson (2013) highlight the importance of the level of analysis. They point out that PD should be analysed at firm and personal level, but paralleled, that the national level should also be considered. This leads to an integrated analysis of the perceptions that can capture the different nuances of the construct in its three levels. 
The third study is about the Asian investors compared to the Australians. Zihui, et al. (2008) refer to the fact that Asian investors in China "differ greatly from Australia in economic structure, per capita income, cultural ties with, and geographical proximity to, China". Generally speaking, the literature consider these features as ingredients of the PD construct. The authors highlight that "it is therefore worth investigating whether the determinants of Australian FDI conform to the general pattern of inward FDI in China". Not only objectively measureable determinants are important, but also qualitative ones and they all contribute to the promotion of Australian FDI in China, in terms of policy design.

The fourth result (Buckley, et al. 2012) does not focus on the Chinese marketplace, however the authors consider the distance issue being part of FDI determinants. Their case about Japan and India shows that geographical and psychic distance, on the one hand, and risk averseness on the other hand, may be responsible for the hesitant behaviour of Japanese firms toward India. Results show that Japanese managers keep seeing India as psychically distant from Japan. Nevertheless, in this specific case rather than the notion of PD, it is the institutional factor (Kostova, 1999, Rottig \& Reus 2009) the crucial determinant in Indo-Japanese economic relations because of India's import substitution policy. This is to demonstrate how FDI determinants depend on the country pairs that are taken into account and their characteristics in terms of institution, environment and behaviour. In support of this, Mathews (2006) argues that globalization includes a number of processes and phenomena next to integration of financial systems, trade liberalization, deregulation and market opening, that is, an orientation toward a cultural, economic and social homogeneity. Nevertheless, if we look at specific cases, especially if we consider pairs of countries that belong to different continents, this is not the case, for instance, China and Italy. Thus, we can refer to globalization in terms of generalization, but if specific case studies are considered, this generalization is no longer applicable due to a wide range of differences. Under this perspective, PD and cultural distance are called upon: "it is exactly here where the countries involved in the comparison collides or unify or even complement themselves" (Mathews, 2006).

The fifth work on Malaysian FDI into China (Hashim, 2012) demonstrates that PD plays a pivotal role in foreign expansion strategies. The author supports the applicability of the Uppsala incremental process of internationalization and the positive role played by the awareness of PD perception, which reduces uncertainties and risks of failure in foreign markets. The sixth and last one (Amighini, et al. 2013) also supports Hashim's study (2005) by stating that PD and the issue of psychically distant market perceptions do matter. The 
authors emphasize the role of the international relations with overseas Chinese for Chinese companies since they are considered a crucial source of information and location attraction factors.

According to the theoretical background which provides with an overview of the main theories applicable in FDI decisions, PD is a key element of the Uppsala internationalization model (Johanson \& Vahlne, 1977; 2009). The following articles support this theory (see Table 3.).

Table 3. Articles supporting the role of PD according to Uppsala

\begin{tabular}{lll}
\hline Authors & Year of publication & Academic journal \\
\hline Walters, P.G.P. & 1996 & International Journal of Information Management \\
\hline Dunning, J.H. & 2000 & International Business Review \\
\hline Xu, D., Shenkar, O. & 2002 & Academy of Management Review \\
\hline Stoian, C., Filippaios, F. & 2008 & International Business Review \\
\hline Luo, Y., Shenkar, O. & 2011 & Journal of International Management \\
\hline Luiz, J.M., Ruplal, M. & 2013 & Emerging Markets Finance and Trade \\
\hline Ambos, B., Håkanson, L. & 2014 & Journal of International Management \\
\hline
\end{tabular}

(Source: own elaboration)

An exceptional investigation on PD highlights the fact that perception of familiarity and similarity across countries, for example English speaking countries, is not always synonym of closeness (Henderson, 2005). As a matter of fact, over-confidence, which may rely on language and cultural related aspects, may lead to distorted perceptions and can have a negative impact on the business communication processes as well as personal relationships ${ }^{6}$. Although evidences show that the issue of non-physical distance does not appear consistently among the main FDI determinants, many scholars in international business and international management have been trying go deep on it, at the same time, being aware of the subjectivity of the concept. Rather than focusing on the second word of the terms pairs "psychic distance" and "cultural distance" (thus, on "distance") a deeper analysis of the relationship between the "psychic" and "cultural" term may be necessary. For example, Spigarelli (2010), Al-Huda and Karim (2012) confirm the steady interest in the two strongly related constructs. Spigarelli (2010) refers to "psychological distances" and relates it to "cultural affinity", while Al-Huda

\footnotetext{
${ }^{6}$ This is known as the PD paradox (O’Grady \& Lane, 1996).
} 
and Karim (2012) argue that the psychic distance concept includes the cultural factor next to the geographical, legal and linguistic variables. It can be noticed that the two issues play a quite relevant role in the international literature and scholars keep analyzing them.

\section{DISCUSSION}

It is clear that the evidences analyzed in this paper show how PD has its valuable space in the literature, but has not been taken into account as much as other economics and quantifiable FDI determinants. The previous sections confirm two directions, the influence of the PD perceptions and of the cultural and political features in the decision making process and the difficulty to quantify and measure such variables in the area of international business. As a matter of fact, several scholars have tried to study and measure those subjective variables. Hofstede (1980) is a clear example and other indexes elaborated in subsequent studies over the years are based on his composite index (Kogut \& Singh, 1988). Drogendijk and Slangen (2006) support the validity of the cultural distance indexes proposed by Hofstede (1980) and later by Schwartz in 1994, who elaborated another composite index based on his colleague's work. According to the authors Drogendijk and Slangen (2006), it is premature to dismiss these indexes and consider them as outdated or inaccurate.

\subsection{The case of China: relevant findings}

Recently China has been one of the most studied cases by international scholars (Parmentola, 2011; Villaverde \& Maza, 2012). However, only 25 articles resulting from the search procedures illustrated above cover the Chinese marketplace, FDI determinants and PD issues all together. Shedding light on the issue of direction, scholars identify in-, out-, and intracountry flows. The peculiarity of outbound FDI is worth mentioning as 3 articles out of 25 resulted from the search. This shows how China is not only one of the largest recipients of FDI, but it is also starting to play an active role worldwide as far as outbound FDI is concerned (Spigarelli, 2010; Unctad, 2013). Largely in developed economies a gradual recovery of FDI is expected in the current year and 2015 and focusing on figures on China, it can be assumed that this phenomenon will be deeper investigated by scholars from the very near future onward. This forecast is supported by the role played by cultural or historical ties of Chinese residents with other Chinese abroad or overseas Chinese, that may be crucial resources in explaining outward-trends of FDI. Thanks to these relations and the presence of Chinese in the rest of the world, the ability to exploit ties within the same ethnic networks 
worldwide is proven to be fundamental. Spigarelli (2010) confirms that "cultural affinity goes along with psychological closeness perceptions". This intertwines with the geographical viewpoint, for example, Chinese investment in Italy is strongly related to the local presence of Chinese residents (the city of Prato in Tuscany region).

An increasing knowledge of foreign markets by multinational firms is gained through experience from the interaction between factors captured by the concept of "psychic distance", that seems to include not only cultural, legal and linguistic elements, but also geographical variations between two locations of business activity (Al-Huda \& Karim, 2012) and legal, normative and cognitive aspects which draw from institutional theories (Scott, 1995; Kostova, 1999; Rottig \& Reus, 2009).

According to Amighini and colleagues (Amighini, et al. 2013), international guanxi among the Chinese Diaspora seems to be a relevant attraction factor in location decisions. In other words, exploitation of relational assets reduce PD with institutionally different countries. For this reason, local network of overseas Chinese are considered a crucial source of information and trustworthiness - for Chinese companies in a psychically distant market and can reveal the success or the failure of the investment or business. Entrepreneurship is a dynamic activity, between 2004 and 2007 the presence of the Chinese entrepreneurs increased by 45\%. Scholars refer to "ethnic specialization", meaning a concentration of Chinese entrepreneurs in specific business segments and about "industry ethnicization", that is the trend of this ethnic group to saturate business initiatives of initial establishment. Next to this, they tend to favour district areas that offer a wide range of peculiar skills.

The impact of transnational ties in the realm of FDI is crucial, as the author illustrates a striking example of "how the presence of potential political and military public interests may impede international integration transactions" (Spigarelli, 2010). In support of this, Chen, et al. (2004) argue that in least institutionalized markets such as Southeast Asia, initial network connections with related firms and ethnic links to Chinese Diaspora play an important role in facilitating and fostering FDI. The authors emphasize the role of cultural background and affinity, also confirmed by Spigarelli (2010) .

\section{2 "Affinity" in cultural, background, and institutional features}

Next to this, there are other non-economic factors which are argued to affect both the amount of direction of investment flows, such as bureaucratization of authorization procedures, that might be related to institutional features. The focus on intangible assets, such as government policies, can be reflected in institutional distance, since government and companies are 
connected in interventions and reforms, therefore affecting the managerial culture and the risk perceptions (Spigarelli, 2010). As far as bureaucratic difficulties, we can find a certain degree of symmetry, which should be further examined. Such issues affect the decision making of an investment in a specific country, including symmetric weaknesses encountered mutually by country A toward country B and by country B toward country A. This is consistent with what the Uppsala School predicts in considering historical, economic and cultural ties between the home and host economy at the initial stage of the internationalization process. And at a later stage, countries with low PD are taken into account thanks to the capitalization of experience after moving into other more distant economies (Stoian \& Filoppaios, 2007). Besides, the reexamination of the Uppsala model by Johanson and Vahlne (2009) confirms that PD insists to be important - it appears to has weakened though. A company network may transcend the geographical boundaries and internationalize through the exploitation of business network opportunities, drawing the conclusion that the selection criterion for mining FDI depends on minimization of the distance between the home country and the host country (Luiz \& Ruplal, 2013).

\section{CONCLUSION}

The present study demonstrates how PD as a determinant of Chinese FDI flows is underinvestigated in the international literature. However, scholars have worked on the distance issue over the years since it first appeared under various perspectives and considering a variety of features, drawing from the extant theories. The reasons may lie in the need for international business research areas to quantify variables in empirical studies and to an under-estimation of the power of PD perceptions at the different levels of analysis individual, firm, group, organization and country level. As about the models used to isolate the PD variable, no consistent material was found in the methodology of the analysed works. The main findings illustrated in this research can be considered as a premise to confirm the need for further research in this field.

China is now widening its presence abroad, not only in the Eastern world regions, but also in the West. This means that Chinese investors have to carry out an attentive examination of FDI determinants regarding the distance issues (e.g. psychic, cultural, institutional, and geographical) next to the mere economic and objectively measurable factors, which are traditionally taken into account. 
If studies have covered the relationships between the Western and Eastern economies so far, being China a passive actor, now an inversion of trend in research is necessary to predict and to analyse the impact that such a big country, in terms of market figures and potentials, has toward other worldwide actors in the various stages of preceding, setting up and carrying on investment.

As a work-in-progress study within Poreen, the final results of the research are not available yet. A questionnaire covering not only economic aspects but also differences in the regulative system, language, culture, and perceptions is currently being submitted to a wide range of companies operating in the green sector and environmental industry in China and Europe ${ }^{7}$ Two future lines of research can follow this study. On the one hand, the elaboration of a theoretical framework aiming at explaining the role of "differences" between Europe and China, considering the various features examined in this research and considering the individual, firm and country levels. On the other hand, this framework can be tested thanks to the data collected through the survey addressed to the European firms investing in China and vice-versa, the Chinese firms operating in Europe.

\section{REFERENCES}

Al-Huda, N., Karim, A. (2012), "Factors affecting foreign direct investment in Malaysia's manufacturing sector: An analysis across states", The Singapore Economic Review, Vol. 57 No. 4, pp. 1-14.

Alon, I., Kellerman, E.A. (1999), "Internal antecedents to the 1997 Asian economic crisis", Multinational Business Review, Vol. 7 No. 2, pp. 1-12.

Alon, I., Rottig, D. (2013) "Entrepreneurship in emerging markets: New insights and directions for future research, Thunderbird International Business Review, Vol. 55 No. 5, pp. 487-492.

Ambos, B., Håkanson, L. (2014), “The concept of distance in international management research”, Journal of International Management, Vol. 20 No. 1, pp.1-7.

Amighini, A.A., Rabellotti, R. Sanfilippo, M. (2013), "Do Chinese state-owned and private enterprises differ in their internationalization strategies?", China Economic Review, Vol. 27, pp. 312-325.

Anderson, G., Ge, Y. (2004), "Do economic reforms accelerate urban growth? The case of China, Urban Studies”, Vol. 41 No. 11, pp. 2197-2210.

\footnotetext{
${ }^{7}$ The questionnaire is available in two versions in order to near both Chinese and European respondents: the Chinese version is addressed to the Chinese investors in Europe and the English version to the European firms investing in China.
} 
Athukorala, P.C., Waglé, S. (2011), "Foreign direct investment in Southeast Asia. Is Malaysia falling behind?", ASEAN Economic Bulletin, Vol. 28 No. 2, pp. 115-133.

Aulakh, P.S. (2007), "Emerging multinationals from developing economies: Motivations, paths and performance", Journal of International Management, Vol. 13 No. 3, pp. 235-402.

Bartels, F.L., Napolitano, F. Tissi, N.E. (2014), "FDI in Sub-Saharan Africa: A longitudinal perspective on location-specific factors (2003-2010)", International Business Review, Vol. 23, pp. 516-529,

Beckerman, W. (1956), Distance and the pattern of intra-European trade, The Review of Economics and Statistics, Vol. 38 No. 31, pp. 31-40.

Brewer, P. (2007), "Psychic distance and Australian export market selection", Australian Journal of Management, Vol. 32 No. 1, pp. 73-94.

Brouthers, K.D., Brouthers, L.E., Werner, S. (1996), "Dunning's eclectic paradigm theory and the small firm: The impact of ownership and local advantages on the choice of entry modes in the computer software industry", International Business Review, Vol. 5 No. 4, pp. 337-394.

Brouthers, L.E., Brouthers, K.D., Werner, S. (1999), "Is Dunning's eclectic framework descriptive or normative?", Journal of International Business Studies, Vol. 30 No. 4, pp. 831844.

Brouthers, K.D., Brouthers, L.E., Werner, S. (1996), "Is Dunning's eclectic framework descriptive or normative?", Journal of International Business Studies, Vol. 30 No. 4, pp. 831844.

Buckley, P.J., Cross, A.R., Horn, S.A. (2012), "Japanese foreign direct investment in India: An institutional theory approach", Business History, Vol. 54 No. 5, pp. 657-688.

Chakrabarti, A. (2001), “The determinants of foreign direct investments: Sensitivity analyses of cross-country regressions" Kyklos, Vol. 54 No. 1, pp 89-114.

Chantasasawat, B., Fung, K.C., Iizaka, H., Siu, A. (2004), “The giant sucking sound: Is China diverting foreign direct investment from other Asian economies?", Asian Economic Papers, Vol. 3 No. 3, pp. 122-140.

Chantasasawat, B., Fung, K.C., Iizaka, H., Siu, A. (2010), "FDI flows to Latin America, East and Southeast Asia, and China: Substitute or complements?", Review of Development Economics, Vol. 14 No. 3, pp. 533-546.

Chen, C. (1996), "Regional determinants of foreign direct investment in Mainland China", Journal of Economic Studies, Vol. 23 No. 2, pp. 18-30.

Chen, H., Chen, T.-J. (1998), "Network linkages and location choice in foreign direct investment”, Journal of International Business Studies, Vol. 29 No. 3, pp. 445-467. 
Chen, T.-J., Chen, H., Ku, Y.-H. (2004), "Foreign direct investment and local linkages", Journal of International Business Studies, Vol. 35, pp. 320-333.

Cheng, Y-M. (2006), "Determinants of FDI mode choice: Acquisition, brownfield, and greenfield entry in foreign markets", Canadian Journal of Administrative Sciences Revue, Vol. 23 No. 3, pp 202-220.

Cheng, L.K., Kwan, Y.K. (2000), "What are the determinants of the location of foreign direct investment? The Chinese experience", Journal of International Economics, Vol. 51, pp. 379400.

Child, J., Rodrigues, S.B., \& Frynas, J.G. (2009), "Psychic distance, its impact and coping modes: Interpretations of SMEs decision-makers", Management International Review, Vol. 49 No. 2, pp. 199-224.

Coughlin, C.C., Segev, E. (2000), "Foreign direct investment in China: A spatial econometric study", The World Economy, Vol. 3 No.1, pp. 1-23.

Dow, D., Karunaratna, A. (2006), "Developing a multidimensional instrument to measure psychic distance stimuli”, Journal of International Business Studies, Vol. 37 No. 5, pp. 578602.

Drogendijk, R., Slangen, A. (2006), „Hofstede, Schwartz, or managerial perceptions? The effects of different cultural distance measures on establishment mode choices by multinational enterprises", International Business Review, Vol. 15, pp. 361-380.

Dunning, J.H. (1958), American Investment in British Manufacturing Industry, London: George Allen and Unwin.

Dunning, J.H. (1993), Multinational Enterprises and the Global Economy, Harlow: AddisonWesley.

Dunning, J.H., Bansal, S. (1997), "The cultural sensitivity of the eclectic paradigm", Multinational Business Review, Vol. 5 No. 1, pp. 1-16.

Dunning, J.H. (1980), “Toward an eclectic theory of international production: Some empirical tests", Journal of International Business Studies, Vol. 11 No. 1, pp. 9-31.

Dunning, J.H. (1988), "The eclectic paradigm of international production: A restatement and some possible extensions", Journal of International Business Studies, Vol. 19 No. 1, pp. 1-31.

Dunning, J.H. (1981), "Explaining the international position of countries towards a dynamic or developmental approach", Weltwirtschaftliches Archiv, Vol. 117, pp. 30-64.

Dunning, J.H. (1986), “The investment development path revisited”, Weltwirtschaftliches Archiv, Vol. 122, pp. 667-677. 
Dunning, J.H. (2000), "The eclectic paradigm as an envelope for economic and business theories of MNE activity", International Business Review, Vol. 9, pp. 163-190.

Dunning, J.H. (2001), “The eclectic (OLI) paradigm of international production: Past, present and future", Journal of International Economics of Business, Vol. 8 No. 2, pp. 173-190.

Dunning, J.H. (2006), “Comment on Dragon multinationals: New players in $21^{\text {st }}$ century globalization”, Asia Pacific Journal of Management, Vol. 23 No. 2, pp. 139-141.

Dunning, J.H. Kim, C.-S., Lin, J.-D. (2001), "Incorporating trade into the investment development path: A case study of Korea and Taiwan”, Oxford Development Studies, Vol. 29 No. 2, pp. 145-154.

Dunning, J.H., Pak, Y.S., Beldona, S. (2007), "Foreign ownership strategies of UK and US international franchisors: An exploratory application of Dunning's envelope paradigm", International Business Review, Vol. 16, pp. 531-548.

Dunning, J.H. (2009), "Location and the multinational enterprise: John Dunning's thoughts on receiving the Journal of International Business Studies 2008 Decade Award”, Journal of International Business Studies, Vol. 40, pp. 20-34.

Cushman, D.O. (1985), "Real exchange rate risk, expectations and the level of direct investment", Review of Economics and Statistics, Vol. 67 No. 2, pp. 297-308.

Ferreira, M.P., Pinto, C.F., Serra, F.A.R., Gaspar, L.F. (2011), “John Dunning's influence in international business/strategy research: A bibliometric study in the strategic management journal”, Journal of Strategic Management Education, Vol. 7 No. 2, pp. 77-99.

Forsgren, M. (2002), “The concept of learning in the Uppsala internationalization process model: A critical review", International Business Review, Vol. 11, pp. 257-277.

Fung, K.C., Garcia-Herrero, A., Iizaka, H., Siu, A. (2005), "Hard or soft? Institutional reforms and infrastructure spending as determinants of foreign direct investment in China", The Japanese Economic Review, Vol. 56 No. 4, pp. 408-416.

Ghemawat, P. (2001), "Distance still matters", Harvard Business Review, Vol. 79 No. 8, pp. 137-147.

Gomez-Mejia, L., Polick, L., (1997), "Cultural diversity and the performance of multinational firms", Journal of International Business Studies, Vol. 28 No. 2, pp. 309-335

Grosse, R., Trevino, L.J. (1996), "Foreign direct investment in the United States: An analysis by country of origin”, Journal of International Business Studies, Vol. 27 No. 1, pp. 139-155.

Gruber, W.H., Vernon, R. (1970), “The technology factor in a world trade matrix" (Ed. Vernon, R.), The Technology Factor in International Trade, National Bureau of Economic Research, New York: 233-272. 
Guisinger, S. (2001), "From OLI to OLMA: Incorporating higher levels of environmental and structural complexity into the eclectic paradigm", International Journal of the Economics of Business, Vol. 8 No. 2, pp. 257-272.

Hashim, F. (2012), "Outward internationalization and FDI: Motives for Malaysian MNEs moving into China”, Review of Business \& Finance Studies, Vol. 3 No. 2, pp. 89-102.

Heiner, R., (1985), “Origins of predictive behavior: Further modeling applications”, American Economics Review, Vol. 75 No. 2, pp. 391-396.

Hennart, J.F. (1982), A Theory of Multinational Enterprise, Ann Arbor, University of Michigan.

Hennart, J.F., Larimo, J. (1998), “The impact of culture on the strategy of multinational enterprises: Does national origin affect ownership decisions?", Journal of International Business Studies, Vol. 29, pp. 515-538.

Henderson, J.K. (2005), "Language diversity in international management teams", International Studies of Management \& Organization, Vol. 35 No. 1, pp. 66-82.

Hofstede, G. (1980), Culture's consequences: International differences in work-related values. Beverly Hills, CA: Sage.

Hong, J. (2007) "Firm-specific effects on location decisions of foreign direct investment in China’s logistics industry”, Regional Studies, Vol. 41 No. 5, pp. 673-683.

Hong, M., Chen, L.S. (2001), "Quantitative and dynamic analysis of the OLI variables determining FDI in China", Review of Urban and Regional Development Studies, Vol. 13 No. 2, pp. 163-172.

Hosseini, H. (2005), "An economic theory of FDI: A behavioural economics and historical approach", The Journal of Socio-Economics, Vol. 34, pp. 528-541.

Hymer, S.H. (1960), The International Operation of National Firms: A Study of Direct Investment. M.I.T [Ph.D. dissertation], Published by M.I.T. Press in 1976.

Iwasaki, I., Suganuma, K. (2005), "Regional distribution of foreign direct investment in Russia", Post-communist Economies, Vol. 17 No. 2, p.153-172.

Jajri, I. (2009), "Foreign direct investment and economic growth: Cointegration techniques", The IUP Journal of Managerial Economics, Nos. 3,4, pp. 7-18.

Jiang, F. (2006), “The determinants of the effectiveness of foreign direct investment in China: An empirical study of joint and sole ventures", International Journal of Management, Vol. 23 No. 4, pp. 891-908. 
Johanson, J., Vahlne, E. (1977), "The internationalization process of the firm: A model of knowledge development and increasing foreign market commitments", Journal of International Business Studies, Vol. 8, pp. 23-32.

Johanson, J., Vahlne. E. (2009), “The Uppsala internationalization process model revisited: From liability of foreignness to liability of outsidership", Journal of International Business Studies, Vol. 40 No. 9, pp. 1411-1431.

Karim, N.A-H.A. (2012) "Factors affecting foreign direct investment in Malaysia's manufacturing sector: An analysis across states", The Singapore Economic Review, Vol. 57 No. 4, pp. 1-14.

Kogut, B., Singh, H. (1988), "The effect of national culture on the choice of entry mode", Journal of International Business Studies, Vol. 19, pp. 411-432.

Kostova, T. (1999) "Transnational transfer of strategic organizational practices: A contextual perspective", Academy of Management Review, Vol. 24 No. 2, pp. 308-324.

Langhammer, R.J. (1991), "Towards regional entities in Asia-Pacific”, ASEAN Economic Bulletin, Vol. 7 No. 3, pp. 277-289.

Lattemann, C., Alon, I., Chang, J., Fetscherin, M., McIntyre, J.R. (2012), “The globalization of Chinese Enterprises”, Thunderbird International Business Review, Vol. 54 No. 2, pp. 145-153. Leamer, E.E. (1974), "The commodity composition of international trade in manufactures: An empirical analysis”, Oxford Economic Papers, Vol. 26 No. 3, pp.350-374.

Lenartowicz, T., Roth, K., (1999), “A Framework for culture assessment”, Journal of International Business Studies, Vol. 30 No. 4, pp. 781-798.

Li, X., Hou, K., Chan, M.W.L. (2008), “An empirical study of foreign direct investment location in Eastern China”, The Chinese Economy, Vol. 41 No. 6, pp.75-98.

Liao, H., Liu, X., Wang, C. (2012), “Knowledge spillovers, absorptive capacity and total factor productivity in China's manufacturing firms", International Review of Applied Economics, Vol. 26 No. 4, pp. 533-547.

Linnemann, H. (1966), An Econometric Study of International Trade Flows, North-Holland Publishing Company, Amsterdam.

Littrell, R.F., Alon, I., Chan, K.W. (2012), "Regional differences in managerial leader behavour preferences in China", Cross Cultural Management, Vol. 19, No. 3, pp: 315-335.

Luiz, J.M., Ruplal, M. (2013), "Foreign direct investment, institutional voids, and the internationalization of mining companies into Africa", Emerging Markets Finance and Trade, Vol. 49 No. 4, pp. 113-129. 
Luo, Y., Shenkar, O. (2011), "Toward a perspective of cultural friction in international business", Journal of International Management, Vol. 17 No. 1, pp. 1-14.

Ma, Z., Yang, R., Zhang, Y. (2008), "Australia's direct investment in China: Trends and determinants”, Economic Papers, Vol. 27 No. 1, pp.70-86.

Markusen, J., (1995), "The boundaries of multinational enterprises and the theory of international trade”, The Journal of Economic Perspectives, Vol. 9 No. 2, 169-191.

Mathews, J.A. (2006), "Dragon multinationals: New players in $21^{\text {st }}$ century globalization", Asia Pacific Journal of Management, Vol. 23 No. 5, pp. 5-27.

McDougall, P., Oviatt, B. (2005), "Defining International Entrepreneurship and modeling the speed of internationalization", Entrepreneurship Theory and Practice, Vol. 29 No. 5, pp. 537554.

North, D.C. (2005), Understanding the process of economic change. Princeton: Princeton University Press.

O’Grady, S., Lane, H. (1996), “The psychic distance paradox,” Journal of International Business Studies, Vol. 27 No. 2, pp. 309-333.

Parmentola, A. (2011), “The internationalization strategy of new Chinese multinationals: Determinants and evolution”, International Journal of Management, Vol. 28 No. 1, pp. 369386.

Ramasamy, B. (2003), "FDI and uncertainty: The Malaysian case", Journal of the Asia Pacific Economy, Vol. 8 No. 1, pp. 85-101.

Ricardo, D., Sraffa, P. (Ed.) (1817), On the Principles of Political Economy and Taxation, Cambridge University Press, 1951.

Roth, K., O’Donnell, S.O. (1996), “Foreign subsidiary compensation: An agency theory perspective", Academy of Management Journal, Vol. 39 No. 3, pp. 678-703.

Rottig, D., Reus, T.H. (2009) "Institutional distance, organizational legitimacy, and the performance of foreign acquisitions in the united states", Academy of Management Annual Meeting Proceedings, pp. 1-6.

Samuelson, P. (1948), "International trade and the equalization of factor prices", Economic Journal, Vol. 58, pp. 163-184.

Sanfilippo, M. (2010), "Chinese FDI to Africa: What is the nexus with foreign economic cooperation?", African Development Review, Vol. 22 No. 1, pp. 599-614.

Scott, W.R. (1995), Institutions and organizations. Sage: Thousand Oaks, CA. 
Shenkar, O. (2001), "Cultural distance revisited: Towards a more rigorous conceptualization and measurement of cultural differences", Journal of International Business Studies, Vol. 32 No. 4, pp. 519-35.

Spigarelli, F. (2009), "Le multinazionali dei paesi emergenti: gli investimenti cinesi in Italia" (MNEs from emerging countries: Chinese investment in Italy. With English summary), Economia Politica e Industriale, Vol. 36 No. 2, pp. 131-159.

Spigarelli, F. (2010), “Chinese investments in Italy: Is the wave arriving?”, International Journal of Asian Business and Information Management, Vol. 1 No. 1, pp. 54-76.

Stoian, C., Filippaios, F. (2008), "Dunning's eclectic paradigm: A holistic, yet context specific framework for analyzing the determinants of outward FDI evidence from international Greek investments", International Business Review, Vol. 17, pp. 349-367.

Tse, D.K., Pan, Y., Au, K.Y. (1997), "How MNCs choose entry modes and form alliances: The China experience”, Journal of International Business Studies, Vol. 28 No. 4, pp. 779-805.

UNCTAD (2014), Global Investment Trends Monitor, No. 15, 28 January, New York, United Nations.

Villaverde, J., Maza, A. (2012), "Chinese per capita income distribution, 1992-2007: A regional perspective", Asian Economic Journal, Vol. 26 No. 4, pp. 313-331.

Vintila, D. (2010), "Foreign direct investment theories: An overview of the main FDI theories, European Journal of Interdisciplinary Studies, Vol. 2 No. 2, pp.104-110.

Vernon R. (1966), "International investment and international trade in the product cycle", Quarterly Journal of Economics, Vol. 80, pp. 190-207.

Walters, P.G.P. (1996), "International market information infusion: Data acquisition behavior in Norwegian Exporters", International Journal of Information Management, Vol. 16 No. 6, pp. 437-444.

Wei, W., Alon, I. (2010) "Chinese outward direct investment: A study on macroeconomic determinants", International Journal and Emerging Markets, Vol. 2 No. 4, pp. 352-369.

Xiaojuan, J., Yingxin, W., Laike, Y. (2004), “A study of the gradual shift of foreign investment", The Chinese Economy, Vol. 37 No. 5, pp. 19-36.

$\mathrm{Xu}$, D., Shenkar, O. (2002), "Institutional distance and the multinational enterprise", Academy of Management Review, Vol. 27 No. 4, pp. 608-618.

Zaheer, S., Schomaker, M.S., Nachum, L. (2012), "Distance without direction: Restoring credibility to a much-loved construct”, Journal of International Business Studies, Vol. 43, pp. $18-27$. 
Zhang, K.H. (2000), "Why is U.S. direct investment in China so small?", Contemporary Economic Policy, Vol. 18 No. 1, pp. 82-94.

Zhang, K.H. (2001a), "China's inward FDI boom and the greater Chinese economy", The Chinese Economy, Vol. 34 No. 1, pp. 74-88.

Zhang, K.H. (2001b), "What attracts foreign multinational corporations to China?", Contemporary Economic Policy, Vol. 19 No. 3, pp. 336-346.

Zhao, S.X.B., Zhang, L. (2007), "Foreign direct investment and the formation of global city regions in China”, Regional Studies, Vol. 14 No. 7, pp. 979-994.

Zheng, P. (2011), "The determinants of disparities in inward FDI flows to the three macroregions of China”, Post-Communist Economies, Vol. 23 No. 2, pp. 257-270.

Zihui, M., Ruilong Y., Zhang, Y. (2008), “Australia's direct investment in China: Trends and determinants", Economic Papers, Vol. 27, pp. 70-86. 